\title{
Correspondence
}

\section{Voluntary euthanasia}

SIR

In his article 'Dealing with the brain-damaged old - dignity before sanctity' (Fournal of Medical Ethics, December 1982), George S Robertson rightly advocates a quality-of-life rather than sanctity-of-life ethic. However, he evinces some misconceptions (that are all too common) about the voluntary euthanasia movement.

For instance, he states that 'EXIT has been active in promoting the concept that such patients should be encouraged to terminate their own lives if they think the need has arisen'. On the contrary: not only do we deplore the idea of persuading anyone in a decision so personal and so irrevocable, but we emphasise the need for as accurate a prognosis as possible of the physical condition that is the cause of the decision before reaching that decision. Moreover, our aim is the legalisation of voluntary euthanasia or assisted suicide (with adequate safeguards), and this would prevent many premature suicides when people learn (or even suspect) that they have a degenerative illness likely to render them incapable of unassisted suicide if they delay too long. What we advocate is a change in the law and in medical practice, so as to allow patients a free choice as to their time and manner of death when they have sufficient reason to desire euthanasia and have given full consideration to all the alternatives. This applies both to active and passive euthanasia.

In the case of senile dementia or of incommunicability, the voluntary principle would be satisfied by the previously known wishes of the patient. Hence the need for legal and medical recognition of the prior declaration (or 'Living Will'), which is already recognised in some European countries and American states.
If there is to be a genuine option, however, it will not be sufficient to put voluntary euthanasia on offer: there must also be the alternative of good professional care for incurables and the best possible terminal care (for example, more hospices). It is ironic that the most vocal opponents of voluntary euthanasia in this country are members of the hospice movement, though we regard that movement as complementary to our own and would like to see many more hospices provided that admission to them and acceptance of a slow death were not compulsory.

Our Guide to Self-Deliverance, far from encouraging suicide, emphasises the alternatives and urges depressives to contact their local Samaritans. In any case, the booklet is primarily a stop-gap, pending the legalisation of voluntary euthanasia.

BARBARA SMOKER Chairman

Voluntary Euthanasia Society (formerly EXIT)

London

\section{Transsexualism and access to a child}

SIR

I was most interested in the article by J $M$ Thomson: 'Transsexualism and access to a child' (I982 8:72), and, as I am the transsexual father of the child referred to throughout the article (I), may I be permitted in your columns to make a few points.

J M Thomson's lucid account of the Appeal Court hearing makes the important point about Ormrod LJ's 'grossly unfair' attitude that the transsexual is somehow responsible for his/her condition, and I was at fault for creating the 'problem' facing my child. This of course flies directly in the face of the considerable body of medical and psychological research on transsexualism, and has probably set the image and acceptance of transsexuals back about 50 years at a time when they are at least becoming more understood by society.

However, Ormrod LJ further went on to make a number of points specifically about my access to my child (viz- my appearance and the child's confusion) which Thomson discusses. I feel it is important to put the record straight on these matters as they are obviously now being accepted and have gone into currency on the basis of the Appeal Court comments by Ormrod LJ. These comments were not based on any evidence whatsoever arising out of the original County Court hearing, a transcript of which is available. All the medical, psychological and welfare reports (2) of the case from all sides made it clear that I had a good close relationship with my child, who although relatively young, was old enough to have understood the nature of what had happened (more so than some adults!) She had known me in my changed gender role, it had been explained to her, and there were no signs whatsoever of psychological disturbance or gender confusion. $N$ Thomson says 'where it is clearly in the $N$ child's interests' access should continue. In fact, once again all the $\omega$ expert evidence given at the original hearing said that it was in her interest 0 that access should continue. Ormrod LJ $\frac{\mathrm{C}}{\mathrm{D}}$ not only chose to ignore all this of evidence, but also unfortunately gave the impression that the facts were other than they were in reality.

With regard to appearance, once again there had been no evidence of my $\varrho$ dressing in any way 'bizarrely', only in the way appropriate to my changed gender role. As a post-operative 
transsexual living and working fully as a female integrated into society, I have continued to see the child regularly, since the case, dressed as any other normal woman, and there have been no problems of any kind whatsoever. Indeed, my ex-spouse and I now have a good relationship, in which the interests of the child are paramount.

Finally, the point about my common-law 'huṣband' visiting the child with me, as he had been doing before the case, needs clarification. The County Court hearing had only temporarily barred him, pending a full report on him and our relationship. This could in theory be presented to the court again and the case for his access re-opened. Once again Ormrod LJ ruled on a matter for which he had no evidence.

That this should be the result of the Appeal Court hearing is perhaps not surprising when one considers that, ironically, Ormrod LJ was the judge in the Corbett v Corbett (I97I) case (April Ashley) which defined the legal status of transsexuals in such a prejudicial way.

\section{References}

(I) G v G I98I.

(2) Richard Green, Professor, Department of Psychiatry and Behavioural Science and Professor, Department of Psychology, University of New York; J M Annear, Consultant Psychiatrist, Guy's Hospital; Margaret Branch, Counseller, ex-Albany Trust, and Court Welfare Officer.

NAME AND ADDRESS SUPPLIED

\section{News and Notes \\ Medical Association for Prevention of War}

The Spring 1983 issue of the fournal of the Medical Association for Prevention of War (MAPW) includes original articles by consultant psychiatrist John Robinson on 'The Last Wars' and by consultant physician Douglas Holdstock on 'The Cost of the Arms Race'. Papers presented at the MAPW conference on 'The Human Cost of Wars since 1945' by Gwyn Prins, historian, Mary Kaldor, economist, Jim Howard of Oxfam and Malcolm Harper, Director of the United Nations Association (UNA), are published in abridged form. There are also contributions from the thriving Australian branch of MAPW: 'A Nuclear-free Pacific Ocean' by John Ward and a conference report by Richard Kefford, chairman.
Other features are extracts from the Pruvot Report to the European Parliament on War Toys and a description of the UK World Disarmament Campaign, part of a series entitled 'Meet the Peace Movement'.

The journal is a twice-yearly publication of medical concern on nuclear war, non-nuclear war and other forms of social violence. The concept of social violence is taken to extend to violations of human rights and to include social injustices and Third World deprivations.

The journal is free to members of MAPW. Non-members may obtain a copy for $75 p$ (inclusive of postage) from Dr Jeffrey Segall, 308 Cricklewood Lane, London NW/2 $2 \mathrm{PX}$. 